\title{
Cyproheptadine, an antihistaminic drug, inhibits proliferation of hepatocellular carcinoma cells by blocking cell cycle progression through the activation of P38 MAP kinase
}

Yu-Min Feng ${ }^{1}$, Chin-Wen Feng ${ }^{3}$, Syue-Yi Chen ${ }^{2}$, Hsiao-Yen Hsieh², Yu-Hsin Chen² and Cheng-Da Hsu ${ }^{2 *}$

\begin{abstract}
Background: Hepatocellular carcinoma (HCC) is a major cause of cancer deaths worldwide. However, current chemotherapeutic drugs for HCC are either poorly effective or expensive, and treatment with these drugs has not led to satisfactory outcomes. In a 2012 case report, we described our breakthrough finding in two advanced HCC patients, of whom one achieved complete remission of liver tumors and the other a normalized a-fetoprotein level, along with complete remission of their lung metastases, after the concomitant use of thalidomide and cyproheptadine. We assumed the key factor in our effective therapy to be cyproheptadine. In this study, we investigated the antiproliferative effects and molecular mechanisms of cyproheptadine.
\end{abstract}

Methods: The effect of cyproheptadine on cell proliferation was examined in human HCC cell lines HepG2 and Huh-7. Cell viability was assayed with Cell Counting Kit-8; cell cycle distribution was analyzed by flow cytometry. Mechanisms underlying cyproheptadine-induced cell cycle arrest were probed by western blot analysis.

Results: Cyproheptadine had a potent inhibitory effect on the proliferation of HepG2 and Huh-7 cells but minimal toxicity in normal hepatocytes. Cyproheptadine induced cell cycle arrest in HepG2 cells in the G1 phase and in Huh-7 cells at the G1/S transition. The cyproheptadine-induced G1 arrest in HepG2 cells was associated with an increased expression of HBP1 and p16, whereas the G1/S arrest in Huh-7 cells was associated with an increase in p21 and p27 expression and a dramatic decrease in the phosphorylation of the retinoblastoma protein. Additionally, cyproheptadine elevated the percentage of Huh-7 cells in the sub-G1 population, increased annexin V staining for cell death, and raised the levels of PARP and its cleaved form, indicating induction of apoptosis. Finally, cyproheptadine-mediated cell cycle arrest was dependent upon the activation of p38 MAP kinase in HepG2 cells and the activation of both p38 MAP kinase and CHK2 in Huh-7 cells.

Conclusions: Our results demonstrate that a non-classical p38 MAP kinase function, regulation of cell cycle checkpoints, is one of the underlying mechanisms promoted by cyproheptadine to suppress the proliferation of HCC cells. These results provide evidence for the drug's potential as a treatment option for liver cancer.

Keywords: Hepatocellular carcinoma, Cyproheptadine, Cell cycle arrest, Apoptosis, p38 MAP kinase

\footnotetext{
* Correspondence: cych06390@gmail.com

2Department of Medical Research, Ditmanson Medical Foundation Chia-Yi

Christian Hospital, Chia-Yi, Taiwan

Full list of author information is available at the end of the article
} 


\section{Background}

Hepatocellular carcinoma (HCC) is the predominant primary liver cancer, with over half a million new cases diagnosed annually [1], and is the fifth most frequently diagnosed cancer worldwide [2]. The very poor prognosis of HCC makes it the second leading cause of cancerrelated death, corresponding to an estimated 695,900 deaths annually [2]. In most countries, HCC accounts for $70 \%-85 \%$ of primary liver cancer cases [3]. In Taiwan, HCC has an incidence of approximately 10,000 new cases per year and has been the leading cause of cancer death for the past two decades [4]. HCC is frequently asymptomatic in its early stages; thus, almost $85 \%$ of patients diagnosed with $\mathrm{HCC}$ are in intermediate or advanced stages, for which limited treatment options are available $[5,6]$. Despite extensive application of targeted therapy, current treatment for advanced HCC is still not satisfactory [7]. Therefore, there have been continued interest and active research in developing effective targeted agents for HCC.

Molecular studies in recent years have highlighted various potential therapeutic targets in HCC, including VEGF and FGF, EGFR, HGFR/c-Met, IGFR, survivin, Wnt signaling, Src signaling, the Ras/Raf/p38 MAP kinase (MAPK) pathway, and the PI3K/AKT/mTOR pathway $[6,8,9]$. As a result, a wide range of novel targeted agents for advanced HCC have been developed or are under development. Although the VEGF-targeted agent sorafenib (Nexavar, Bayer Pharmaceuticals) has been shown to have a clinically meaningful overall survival benefit for HCC patients, it produces differential outcomes among HCC patients with different etiologies-for example, hepatitis $C$ virus-related versus hepatitis $\mathrm{B}$ virus-related $\mathrm{HCC}$-pointing to the difficulty of treating HCC [10]. Subsequently, additional targeted agents have been evaluated for $\mathrm{HCC}$-for example, sunitinib, regorafenib, and brivanib-and have proven inferior to sorafenib [10]. Several new agents that have shown promise in phase II trials are still under evaluation. Among officially approved and well-tolerated pharmaceutical drugs, a first-generation antihistaminic drug, cyproheptadine, which is often used to treat allergies [11] and used as an appetite stimulant in cancer patients [12], has been demonstrated to have anticancer activity, including in mantle cell lymphoma, leukemia, and multiple myeloma [13,14]. Two independent post mortem case studies found the highest concentrations of cyproheptadine in bile and liver among different tissues and fluids, with liver-to-blood ratios ranging from 16.2 to 62.8 $[15,16]$, indicating that cyproheptadine is favorably taken up by the liver. In addition, in an unexpected clinical finding, two advanced HCC patients with lung metastases achieved complete tumor remission upon treatment with a combination of cyproheptadine and thalidomide [17]. Taken together, these reports indicate a potent anti-HCC effect for cyproheptadine.
Although cyproheptadine has been shown to inhibit cancer cell growth by suppressing the PI3K/AKT signaling pathway, leading to down-regulation of D-cyclins and subsequently inducing apoptosis [18], the specific effects and mechanisms of action of cyproheptadine have not yet been identified in HCC. It would therefore be intriguing to explore the effects of this drug in $\mathrm{HCC}$ cell lines. Our present study investigated the effects of cyproheptadine on the growth of normal human hepatocytes and two HCC-derived cancer cell lines. The effects of this agent on cell cycle progression and apoptosis in HCC cells were also examined. Finally, we sought to reveal the underlying mechanisms involved in cell cycle arrest induced by cyproheptadine. Our results demonstrate that cyproheptadine induces cell cycle arrest in HepG2 cells through the induction of p38 MAPK, and in Huh-7 cells through the induction of p38 MAPK and CHK2, which mediate the induction of cell cycle regulatory proteins.

\section{Methods}

\section{Ethics statement}

The Ethics Committee of Ditmanson Medical Foundation Chia-Yi Christian Hospital approved this study.

\section{Preparation of cyproheptadine and cell cultures}

Cyproheptadine hydrochloride, purchased from SigmaAldrich (St. Louis, MO), was dissolved in dimethyl sulfoxide (DMSO) at a concentration of $100 \mathrm{mM}$ to provide stock solutions, which were then diluted with cell culture medium to desired concentrations ranging from 20 to $120 \mu \mathrm{M}$. Human HCC cell lines HepG2 and Huh-7 (Food Industry Research and Development Institute, Taiwan), as well as primary normal human hepatocytes (SC-5200, ScienCell Research Laboratories, Carlsbad, CA), were used as cell models. HepG2 and Huh-7 cells were cultured in Dulbecco's modified Eagle's medium supplemented with $10 \%$ fetal bovine serum (FBS), 100 units/ml penicillin, and $100 \mu \mathrm{g} / \mathrm{ml}$ streptomycin. Primary human hepatocytes were cultured in Hepatocyte Medium (ScienCell Research Laboratory, Carlsbad, CA) supplemented with 10\% FBS, 100 units $/ \mathrm{ml}$ penicillin, and $100 \mu \mathrm{g} / \mathrm{ml}$ streptomycin. All cell lines were cultured at $37^{\circ} \mathrm{C}$ under a humidified atmosphere containing $5 \% \mathrm{CO} 2$.

\section{Cell viability assay}

HepG2 and Huh-7 cells and primary human hepatocytes were seeded in 96-well plates at $1 \times 10^{4}$ cells per well and cultured for $24 \mathrm{~h}$. The cells were subsequently starved in culture medium without FBS for $24 \mathrm{~h}$ and then treated with cyproheptadine at various concentrations for $24 \mathrm{~h}$. Cell viability was then determined by using Cell Counting Kit-8 (Sigma, Switzerland) according to the manufacturer's protocol. In brief, the assay was performed with WST-8, which can be bio-reduced 
by cellular dehydrogenases to an orange formazan product that dissolves in cell culture medium. The production of formazan occurs only in living cells at a rate proportional to the number of living cells. After the cells were incubated with WST-8, the light absorbance of the culture medium in each well was measured at 450/655 $\mathrm{nm}$ on a Model 680 Microplate Reader (Bio-Rad, Hercules, CA). Cell viability was calculated relative to the untreated cells using the following equation:

$$
\begin{aligned}
\text { Viability }(\%)= & 100 \times \text { Absorbance of treated group } \\
& \div \text { Absorbance of untreated group. }
\end{aligned}
$$

A graph of cell viability versus concentration of the treatment agent was used to calculate the concentration that would return a cell viability of $50 \%\left(\mathrm{IC}_{50}\right)$. The selectivity index (SI), representing the cytotoxic selectivity of the agent against cancer cells relative to normal cells [19], was calculated from $\mathrm{IC}_{50}$ values as follows:

$$
\begin{aligned}
\mathrm{SI}= & \mathrm{IC}_{50} \text { of the given agent in normal cells } \\
& \div \mathrm{IC}_{50} \text { of the given agent in cancer cells. }
\end{aligned}
$$

\section{Cell cycle analysis}

HepG2 and Huh-7 were seeded in 6-well plates at $2 \times 10^{5}$ cells per well and cultured for $24 \mathrm{~h}$, starved in medium without FBS for $24 \mathrm{~h}$, and then treated with $25-40 \mu \mathrm{M}$ cyproheptadine for $48 \mathrm{~h}$. Single-cell suspensions were prepared from the treated cells by trypsinization and resuspending in phosphate-buffered saline (PBS) and were then fixed with methanol at $4^{\circ} \mathrm{C}$ overnight. The fixed cells were rehydrated and washed twice with PBS before being stained by incubation with $5 \mu \mathrm{g} / \mathrm{ml}$ propidium iodide (Sigma, St. Gallen, Switzerland) and $1 \mathrm{mg} / \mathrm{ml}$ RNase A for $30 \mathrm{~min}$ in the dark at room temperature. The cells were then analyzed on a BD FACSCanto II flow cytometer (BD Biosciences, Franklin Lakes, NJ) with ModFit LT 3.3 as the data analysis software.

\section{Apoptosis detection}

HCC cells were seeded on coverslips in 6-well plates at $2 \times 10^{5}$ cells per well and cultured for $24 \mathrm{~h}$, starved in medium without FBS for $24 \mathrm{~h}$, and then treated with $40 \mu \mathrm{M}$ cyproheptadine for either $24 \mathrm{~h}$ or $48 \mathrm{~h}$. The treated cells, on coverslips, were gently washed with PBS and incubated with annexin V-FITC for $5 \mathrm{~min}$ in the dark at room temperature, followed by fixation in $2 \%$ formaldehyde. Subsequently, the coverslips were inverted on glass slides, and the cells were visualized using a fluorescence microscope (Olympus, Tokyo, Japan).

\section{Western blot analysis}

HepG2 and Huh-7 were seeded in 6-well plates at $2 \times$ $10^{5}$ cells per well and cultured for $24 \mathrm{~h}$, starved in medium without FBS for $24 \mathrm{~h}$, and then treated with 40 $\mu \mathrm{M}$ cyproheptadine for various durations. Total cellular proteins were extracted, and protein concentration was determined for the extracts using the Bio-Rad Protein Assay reagent (Bio-Rad) with bovine serum albumin as a standard. Each lysate $(10 \mu \mathrm{g})$ was resolved on denaturing polyacrylamide gels and transferred electrophoretically to PVDF transfer membranes. After blocking with 3\% blocker (Bio-Rad) in Tris-buffered saline with Tween 20 (TBST), the membranes were incubated at room temperature for $2 \mathrm{~h}$ with primary antibodies-1:5000 diluted antibody against GAPDH; 1:1000 diluted antibody against PARP, p21, p27, Rb (D20), phospho-Rb (Ser795), cyclin D1, p38 MAPK, phospho-p38 MAPK (Thr180/ Tyr182), CHK2, phospho-CHK2 (Thr68), p53 (7F5), or phospho-p53 (Ser20) (Cell Signaling, Danvers, MA); or 1:1000 diluted antibody against $\mathrm{p} 16^{\mathrm{INK} 4 \mathrm{~A}}$ or HBP1 (Millipore, Temecula, CA). Immunoreactive proteins were detected by incubation with horseradish peroxidase-conjugated secondary antibodies for $1 \mathrm{~h}$ at room temperature. After washing with TBST, the reactive bands were developed with an enhanced chemiluminescent HRP substrate detection kit (Millipore, Billerica, $\mathrm{MA}$ ) and identified using the BioSpectrum 800 imaging system (UVP).

\section{Statistical analysis}

Data were expressed either as mean \pm standard deviation (SD) or as a percentage relative to the untreated control. Differences between treated and untreated control groups were analyzed by one-way ANOVA followed by Dunnett's test. Statistical significance was considered at a $P$-value $<0.05$ and at the $95 \%$ confidence level.

\section{Results \\ Cyproheptadine treatment affects human HCC cell proliferation}

We first performed an in vitro cell viability assay to compare the cytotoxicity of cyproheptadine in normal human hepatocytes and in HCC-derived human cancer cell lines. Analysis using Cell Counting Kit-8 revealed significant cytotoxicity of cyproheptadine to HepG2 and Huh-7 cells relative to normal hepatocytes at various concentrations and showed that cyproheptadine inhibited cell proliferation in a dose-dependent manner (Figure 1). A similar pattern was also observed in HepG2 and Huh-7 cells treated with cyproheptadine at a low-dosage range $(0.5-5 \mu \mathrm{M})$ for $48 \mathrm{~h}$ (Additional file 1: Figure S1). The $\mathrm{IC}_{50}$ of cyproheptadine, determined as the concentration of the drug that inhibited cell growth by $50 \%$ after $24 \mathrm{~h}$ of treatment, was found to be 44.4, 44.7, and $118.1 \mu \mathrm{M}$ in HepG2 cells, 


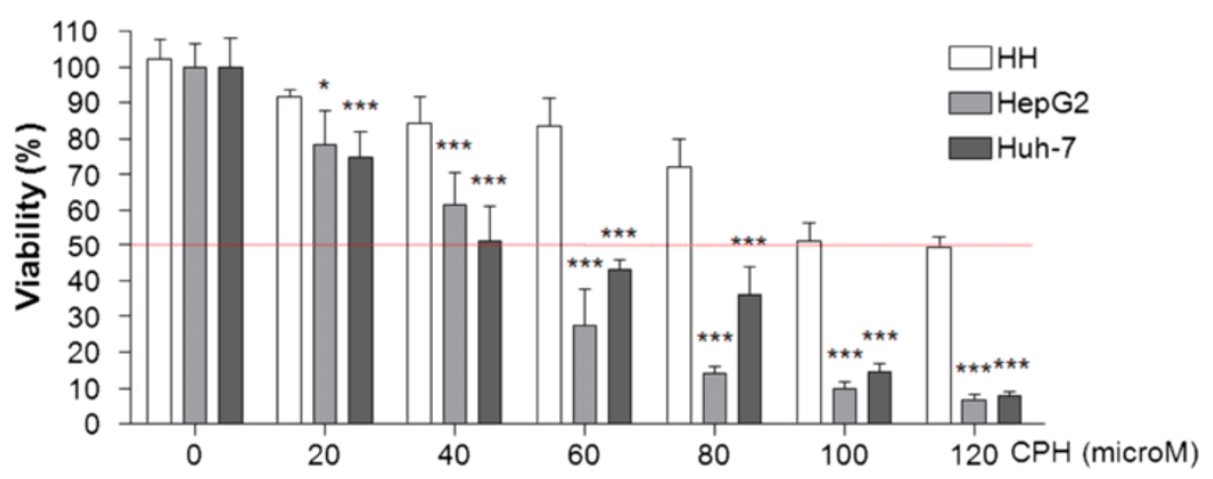

Figure 1 Cytotoxicity of cyproheptadine toward normal human hepatocytes (HH) and HCC cell lines HepG2 and Huh-7. Cells in 96-well plates were cultured for $24 \mathrm{~h}$, starved in serum-free medium for $24 \mathrm{~h}$, and then treated with various concentrations of cyproheptadine for $24 \mathrm{~h}$. Viability was determined for the treated cells using Cell Counting Kit-8. Data are presented as mean \pm SD $(n=6)$. Significant differences from the no-treatment control, determined by one-way ANOVA and Dunnett's comparison test, are indicated by asterisks: ${ }^{*} p<0.05 ;{ }^{* * *} p<0.001$.

Huh-7 cells, and normal human hepatocytes, respectively. Cyproheptadine's highly selective toxicity toward cancer cells is represented by its high selectivity index (SI) values for HepG2 and Huh-7 cells (2.7 and 2.6, respectively; Table 1).

We previously reported the clinical finding that HCC patients achieved complete tumor remission upon treatment with a combination of cyproheptadine and thalidomide [17], which raises the possibility that thalidomide also has an inhibitory effect on HCC cells. Therefore, we used the same in vitro cell viability assay to measure the cytotoxicity mediated by thalidomide in HCC cells. Unexpectedly, thalidomide alone did not result in significant growth inhibition in either HepG2 or Huh-7 cells even when used at high dosage $(200 \mu \mathrm{M})$ for 24 or $48 \mathrm{~h}$ (Additional file 1: Figure S2). These results indicate that thalidomide treatment alone is insufficient to inhibit the proliferation of HCC cells.

\section{Cyproheptadine arrests cell cycle progression in human HCC cells and induces apoptosis in Huh-7 cells}

To explore the possible mechanisms through which cyproheptadine elicits its growth inhibitory effect, we determined if treatment with cyproheptadine hinders the cell cycle progression of HCC cells in concentration ranges close to the $\mathrm{IC}_{50}$ values. As shown by flow

Table 1 Cytotoxic activities of cyproheptadine in HCC cell lines after $24 \mathrm{~h}$ of treatment

\begin{tabular}{lllll}
\hline $\mathbf{I C}_{\mathbf{5 0}}(\boldsymbol{\mu} \mathbf{M})^{\mathbf{a}}$ & & & \multicolumn{2}{l}{ Selectivity index $\left(\mathbf{S I}^{\mathbf{b}}\right)$} \\
\hline $\mathrm{HH}^{\mathrm{c}}$ & HepG2 & Huh-7 & HepG2 & Huh-7 \\
$118.1 \pm 6.4$ & $44.4 \pm 6.1$ & $44.7 \pm 6.1$ & 2.7 & 2.6 \\
\hline
\end{tabular}

${ }^{\mathrm{a}}$ Data are expressed as the means \pm SD of $\geq 4$ replicates.

${ }^{\mathrm{b}} \mathrm{An}$ SI value $>2.6$ indicates a high degree of cytotoxic selectivity.

${ }^{c}$ Normal human hepatocytes. cytometry analysis, exposure to cyproheptadine at 30 and $40 \mu \mathrm{M}$ for $48 \mathrm{~h}$ resulted in a significant increase in the percentage of HepG2 cells in the G0/G1 phase $(p<$ 0.05 and $p<0.001$, respectively; Figure. 2A) while decreasing the percentage in the G2/M phase and in both $S$ and G2/M phases, respectively. In contrast, treatment with 25 and $35 \mu \mathrm{M}$ cyproheptadine for $48 \mathrm{~h}$ significantly increased the percentage of Huh-7 cells in the $\mathrm{S}$ phase $(p<0.05$ and $p<0.001$, respectively; Figure $2 \mathrm{~B}$ ) and decreased the percentage in the G0/G1 phase $(p<0.05$ and $p<0.001$, respectively; Figure 2B).

The above results suggest that cyproheptadine treatment leads to cell cycle arrest in HepG2 cells in the G1 phase and in Huh-7 cells at the G1/S transition. Accordingly, the increase in the proportion of HepG2 cells in G1 was significant at $40 \mu \mathrm{M}$ of cyproheptadine $(\mathrm{p}<$ 0.001 ) and correlated with a reduction in the proportions in $S$ and $G 2 / M(p<0.001)$ at this concentration. Similarly, the increase in the proportion of Huh-7 cells in the $\mathrm{S}$ phase was significant at 25 and $35 \mu \mathrm{M}$ of cyproheptadine $(p<0.05$ and $p<0.001$, respectively) and correlated with a reduction in the proportion in G0/G1 at these concentrations $(p<0.05$ and $p<0.001$, respectively). We also observed that treatment with $35 \mu \mathrm{M}$ cyproheptadine for $48 \mathrm{~h}$ produced a proportionately larger sub-G1 population in the treated Huh-7 cells relative to the untreated control (Figure 2B), indicating induction of cellular apoptosis. Therefore, we further investigated the effect of cyproheptadine treatment at $40 \mu \mathrm{M}$ for different lengths of time ( 24 and $48 \mathrm{~h}$ ) on the induction of apoptosis in HCC cells. As shown by annexin V-FITC binding analysis in Figure 3A (right panel set), cyproheptadinetreated Huh-7 cells were primarily positive for annexin $\mathrm{V}$ staining, indicating that they were undergoing apoptosis. However, significantly annexin V-FITC-positive cells were only sporadically observed in cyproheptadine-treated 

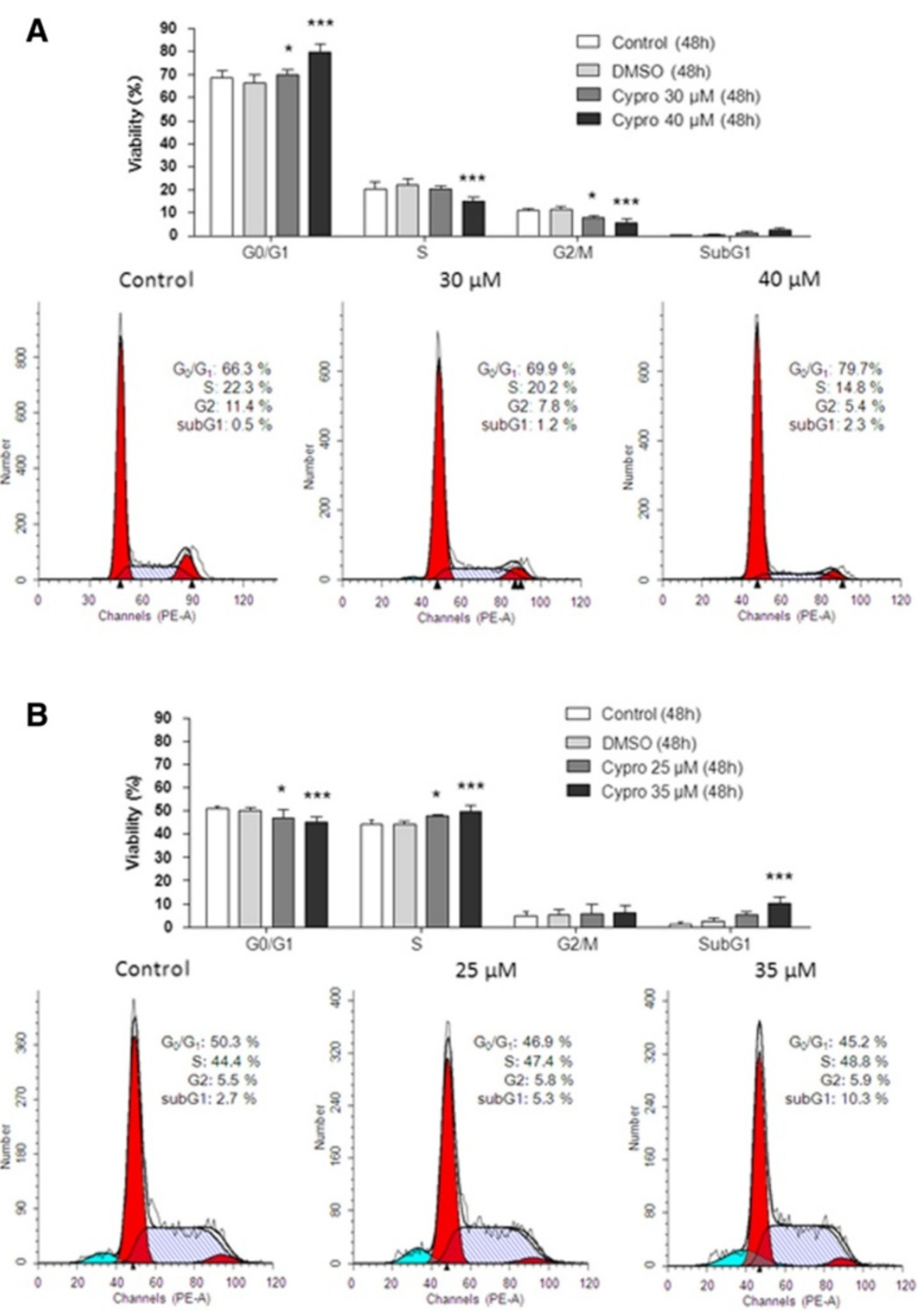

Figure 2 Effects of cyproheptadine on the cell cycle in HCC cells. HepG2 (A) and Huh-7 (B) cells in 6-well plates were cultured for 24 h, starved in serum-free medium for $24 \mathrm{~h}$, and then treated with cyproheptadine at 30 or $40 \mu \mathrm{M}$ (HepG2) or at 25 or $35 \mu \mathrm{M}$ (Huh-7) for 48 h. Treated cells were stained with propidium iodide and analyzed by flow cytometry. Data are presented as mean \pm SD $(n=4)$. Significant differences from the no-treatment control, determined by one-way ANOVA and Dunnett's comparison test, are indicated by asterisks: ${ }^{*} p<0.05$; ${ }^{* * *} \mathrm{p}<0.001$. No difference was observed between the no-treatment control and the DMSO-only control in all test groups, indicating the absence of confounding effects from the DMSO solvent.

HepG2 cells (Figure 3A, left panel set), which is consistent with the result of flow cytometry analysis indicating the lack of a sub-G1 population in cyproheptadinetreated HepG2 cells (Figure 2A). Also, we assessed the effect of cyproheptadine treatment at $40 \mu \mathrm{M}$ for different lengths of time $(0,18,21,24$, and $30 \mathrm{~h})$ on the induction of poly (ADP-ribose) polymerase (PARP) and its cleaved form, which is a hallmark of apoptosis, in HCC cells. As shown by western blot analysis (Figure 3B), the levels of PARP and its cleaved form increased significantly in Huh-7 cells following cyproheptadine treatment for $18-30 \mathrm{~h}$, but decreased in HepG2 


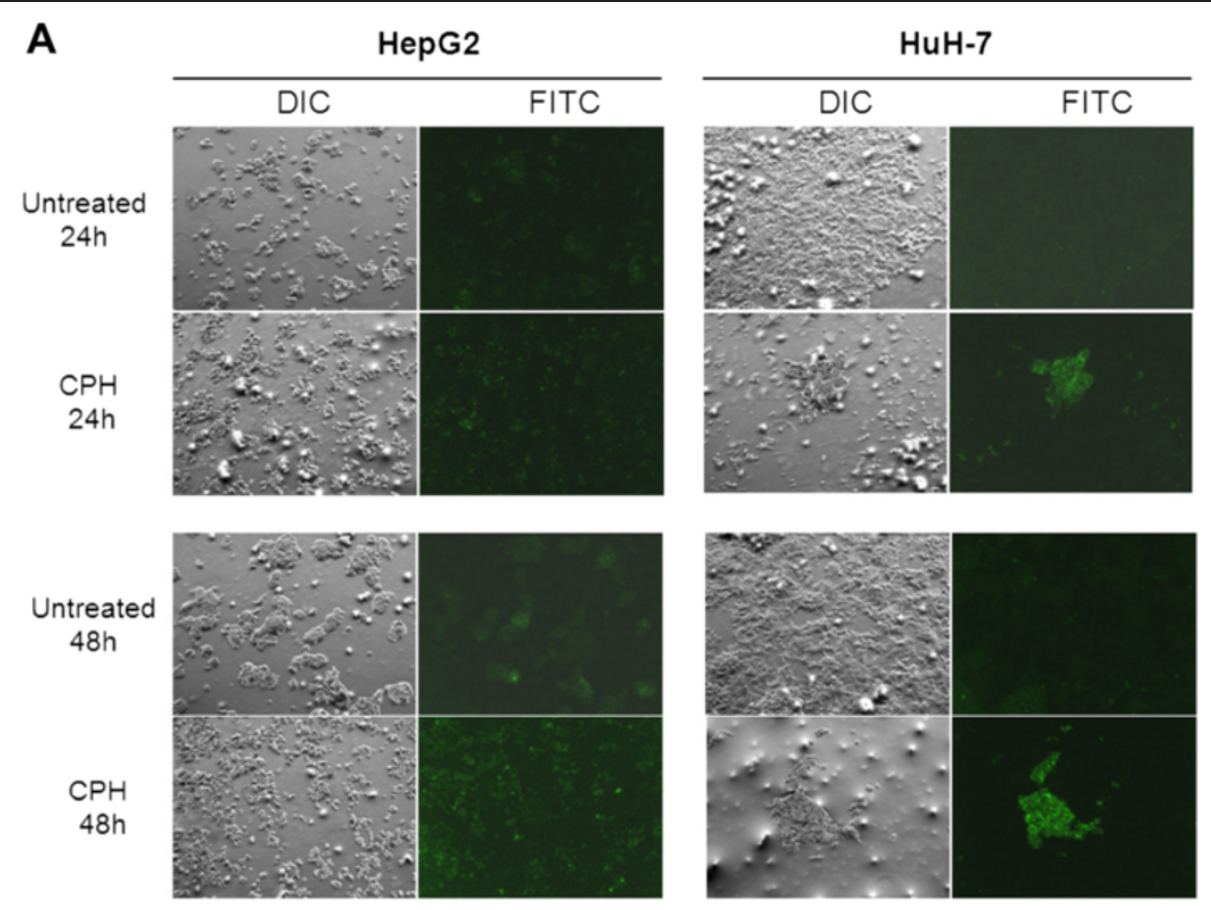

B

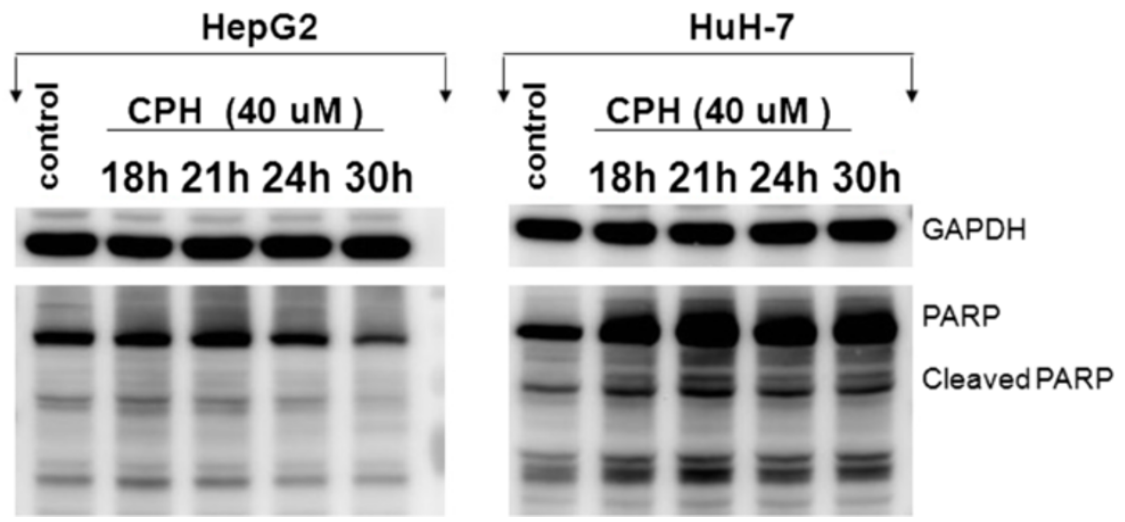

Figure 3 Induction of apoptosis in Huh-7 cells by cyproheptadine. (A) Annexin V staining assay. Cyproheptadine-treated HCC cells were stained with annexin V-FITC and analyzed by fluorescence microscopy. Untreated cells were primarily negative for annexin $V$ staining, indicating that they were viable and not undergoing apoptosis. Treated cells undergoing apoptosis were observed to have positive annexin $V$ staining. (B) Western blot analysis of PARP expression in cyproheptadine-treated HCC cells. The levels of PARP and its cleaved form increased significantly in Huh-7 cells after 18-30 h of treatment, but decreased in HepG2 cells after 24-30 h of treatment.

cells after $24-30 \mathrm{~h}$ of treatment. Together with the significantly increased sub-G1 population in the flow cytometry profile, these results indicate that cyproheptadine induces apoptosis in Huh-7 cells.

\section{Effects of cyproheptadine on cell cycle regulatory proteins}

To elucidate the molecular mechanisms by which cyproheptadine induces cell cycle arrest, we examined the expression of several cell cycle regulatory proteins. HCC cells were treated with $40 \mu \mathrm{M}$ cyproheptadine for different lengths of time and analyzed by western blotting. The results show that the expression of $\mathrm{p} 16^{\mathrm{INK} 4 \mathrm{~A}}$ increased significantly in HepG2 cells following treatment with cyproheptadine for 1-4 h (Figure 4A, left panel set) but did not change significantly in Huh-7 cells (Figure 4A, right panel set). It has been shown recently that the transcription factor HMG box-containing protein 1 (HBP1) targets $\mathrm{p} 16^{\mathrm{INK} 4 \mathrm{~A}}$ through direct sequence-specific binding to its promoter and up-regulates its expression [20]. We 
were thus interested in determining whether the expression profile of HBP1 correlates with that of $\mathrm{p} 16^{\mathrm{INK} 4 \mathrm{~A}}$ in our HCC cell lines. Western blot analysis showed that the expression of HBP1 increased significantly in HepG2 cells following treatment with cyproheptadine for 1-4 h, which matched the pattern of change in $\mathrm{p} 16^{\mathrm{INK} 4 \mathrm{~A}}$ expression in this cell line (Figure 4A, left panel set). In contrast, no significant changes in the level of HBP1 were observed in Huh-7 cells, in keeping with the expression pattern of p $16^{\mathrm{INK} 4 \mathrm{~A}}$ in this cell line (Figure 4A, right panel set).

Next, we analyzed the effect of cyproheptadine on the expression of the cyclin-dependent kinase inhibitors p21 and p27 in HCC cells. As detected by western blotting, the levels of p21 and p27 increased significantly in Huh-7 cells following treatment with cyproheptadine for 1-6 h and $1-4 \mathrm{~h}$, respectively (Figure $4 \mathrm{~A}$, right panel set), but no significant changes in these proteins were observed in HepG2 cells (Figure 4A, left panel set). We also analyzed the effect of cyproheptadine on retinoblastoma protein $(\mathrm{Rb})$ phosphorylation and found a strong time-dependent decrease in the level of phospho-Ser795 Rb in Huh-7 cells but not in HepG2 cells (Figure 4A). In addition, we examined the effect of cyproheptadine on the expression of cyclin D1. Although the level of cyclin D1 did not change in response to cyproheptadine treatment in HepG2 cells (Figure 4B, left panel set), a moderate decrease in cyclin D1 expression was observed in Huh-7 cells after $30 \mathrm{~h}$ of treatment (Figure 4B, right panel set).

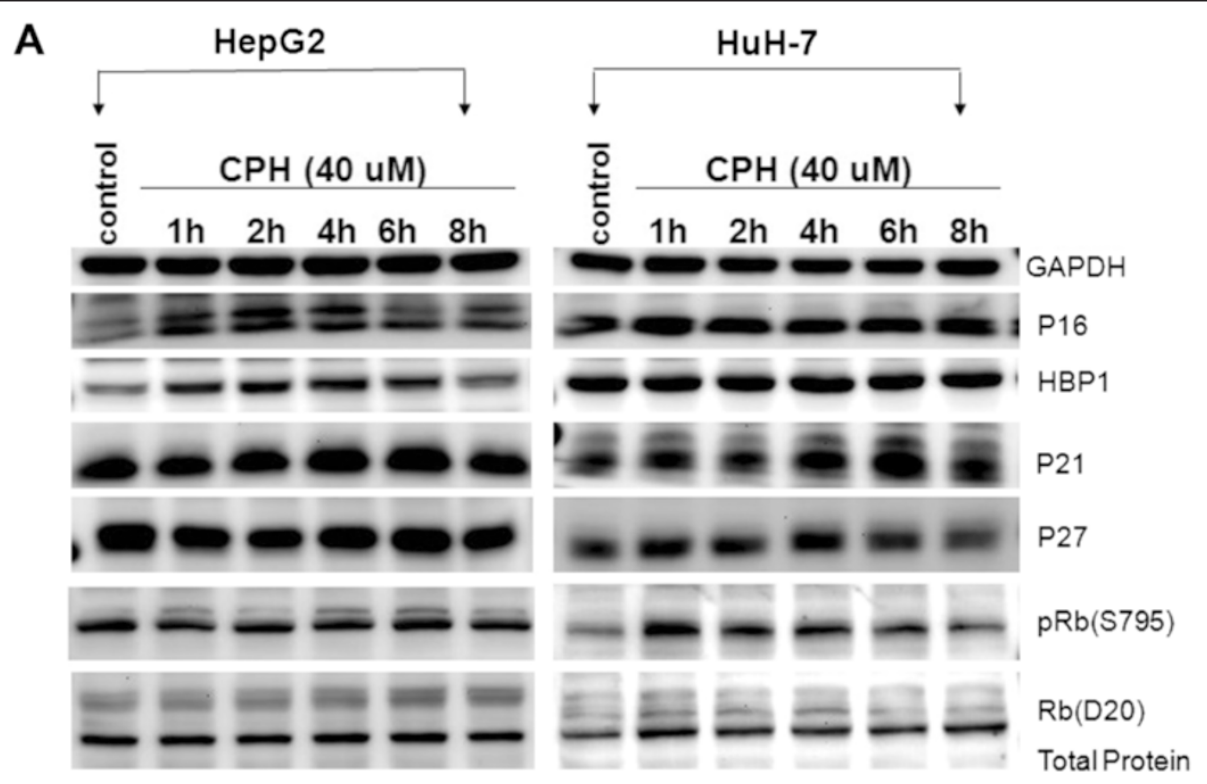

B

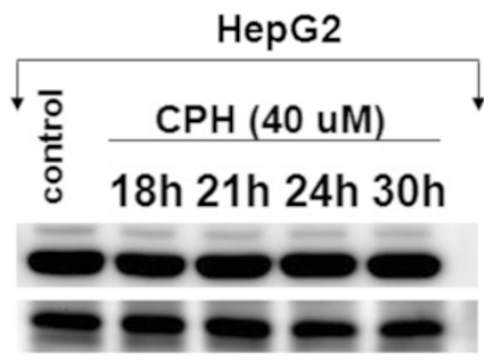

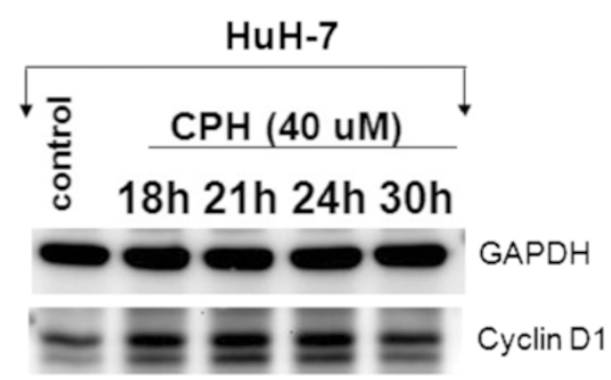

Figure 4 Cyproheptadine alters the expression of cell cycle regulatory proteins. (A) Western blot analysis of the expression of p16, HBP1, p21, p27, Rb, and phospho-Rb in HCC cells treated with $40 \mu \mathrm{M}$ of cyproheptadine for different lengths of time. As shown in the figure, the levels of p16 and HBP1 increased in HepG2 cells after treatment with cyproheptadine for 1-4 h, followed by a gradual decrease during 6-8 h, but did not change significantly in Huh-7 cells. The levels of p21 and p27 increased in Huh-7 cells after $4-6 \mathrm{~h}$ and $1-4 \mathrm{~h}$ of treatment, respectively, but did not change significantly in HepG2 cells. The level of phospho-Ser795 Rb decreased in a time-dependent manner after 2-8 h of treatment in Huh-7 cells, but not in HepG2 cells. (B) Western blot analysis of cyclin D1 expression in cyproheptadine-treated HCC cells. The result shows a moderate decrease in the cyclin D1 level in Huh-7 cells after treatment with cyproheptadine for 30 h, but not in HepG2 cells. 
Cyproheptadine-induced cell cycle arrest involves p38 MAPK activation in HepG2 cells and involves both p38 MAPK and CHK2 activation in Huh-7 cells

Previous studies have demonstrated that p38 MAPK plays a role in cell cycle regulation by activating the cell cycle checkpoints at G2/M and at G1/S in response to cellular stress $[21,22]$. To determine whether the activation of p38 MAPK is involved in cyproheptadine-induced cell cycle arrest, we examined the induction of Thr180/Tyr182phosphorylated p38 MAPK in cyproheptadine-treated HCC cells. Following treatment with $40 \mu \mathrm{M}$ cyproheptadine for different lengths of time, cell lysates were prepared and analyzed by western blotting using antibodies specific for p38 MAPK and Thr180/Tyr182-phosphorylated p38 MAPK. As shown in Figure 5, a significant increase in p38 MAPK activation occurred in both HCC cell lines after treatment for $1 \mathrm{~h}$, as indicated by the increased levels of Thr180/Tyr182-phosphorylated p38 MAPK. The total amount of p38 MAPK was unaffected by cyproheptadine treatment in both cell lines (Figure 5). To validate the role of p38 MAPK in cyproheptadine's effects, SB202190, an inhibitor of p38, was used to assess the effect of p38 inhibition on cyproheptadine-induced p38 MAPK activation and expression of cell cycle-regulating proteins including HBP1, p16 ${ }^{\mathrm{INK} 4 \mathrm{~A}}$, p21, and $\mathrm{p} 27$. We found that, in contrast to the increased p38 MAPK phosphorylation and expression of cell cycle-regulating proteins upon cyproheptadine treatment, co-treatment with SB202190 and cyproheptadine significantly inhibited p38 MAPK phosphorylation in both HCC cell lines, decreased HBP1 and $\mathrm{p} 16^{\mathrm{INK} 4 \mathrm{~A}}$ expression in HepG2 cells, and decreased p27 expression in Huh-7 cells (Additional file 1: Figure S3). These results thus correlate cyproheptadine-mediated increase in p38 MAPK phosphorylation with an immediate increase in HBP1 and p16 ${ }^{\text {INK4A }}$ expression in HepG2 cells and with a subsequent increase in p27 expression in Huh-7 cells.

CHK2 has been found to be dispensable for p53mediated cell cycle arrest $[23,24]$. We were interested in exploring a p53-independent role for $\mathrm{CHK} 2$ in inducing cell cycle arrest because the tumor suppressor p53 is frequently mutated in cancer cells and the Huh-7 HCC cell line used in this study is p53 defective [25]. Using antibodies specific for CHK2, Thr68-phosphorylated CHK2, p53, and Ser20-phosphorylated p53, we detected a timedependent increase in the level of Thr68-phosphorylated $\mathrm{CHK} 2$ and no change in the level of total CHK2 in Huh7 cells (Figure 5, right panel set). In contrast, no significant changes in the levels of phospho-Thr68 CHK2 and total CHK2 were observed in HepG2 cells (Figure 5, left panel set). Furthermore, no significant increase in p53 activation occurred in either HCC cell line following cyproheptadine treatment, as indicated by the absence of significant changes in the level of Thr20-phosphorylated p53. Accordingly, the amount of total p53 was also unaffected by cyproheptadine treatment in both cell lines (Figure 5). These results suggest that cyproheptadine is able to induce CHK2 activation in p53-defective HCC cells to cause cell cycle arrest.

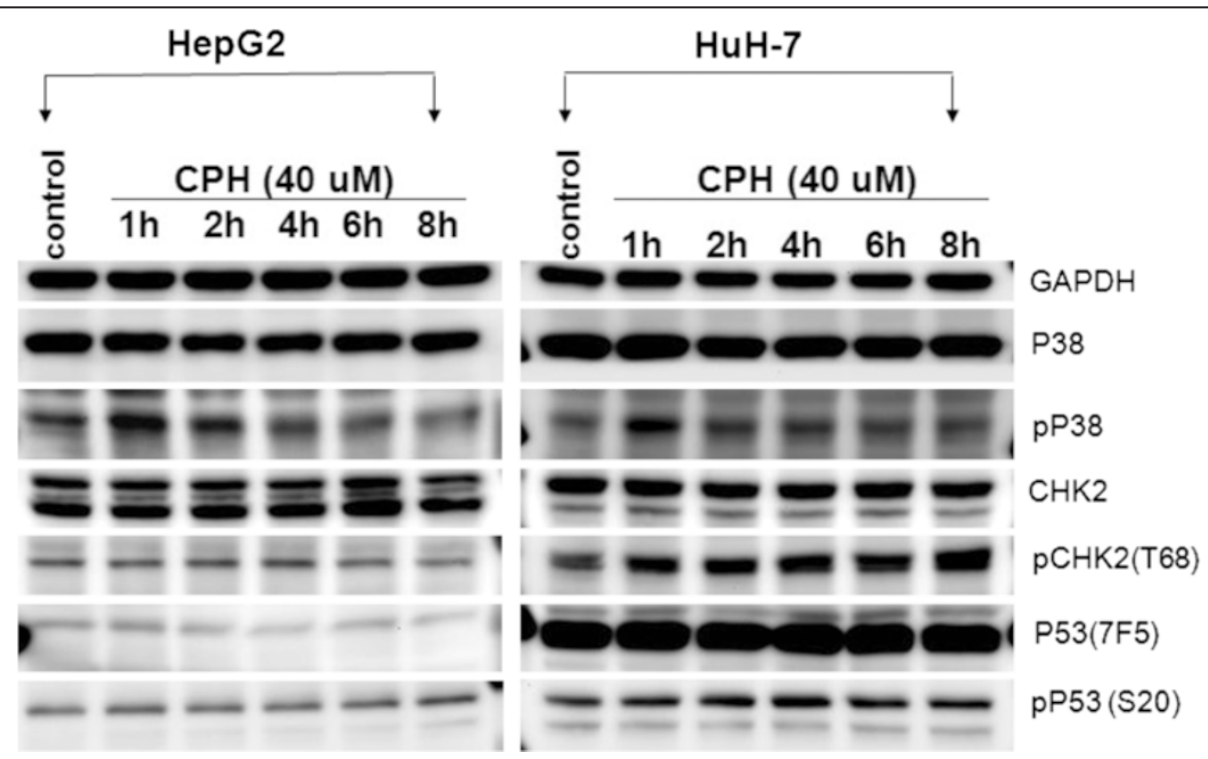

Figure 5 Cyproheptadine induces p38 MAPK activation in HepG2 cells and activation of p38 MAPK and CHK2 in Huh-7 cells. Western blot analysis was performed to detect p38, CHK2, p53, and their phosphorylated forms in HCC cells following treatment with $40 \mu \mathrm{M}$ cyproheptadine for different lengths of time. The level of Thr180/Tyr182-phosphorylated p38 MAPK markedly increased in both HCC cell lines after $1 \mathrm{~h}$ of treatment, indicating p38 MAPK activation. The level of Thr68-phosphorylated CHK2 increased independently of the level of Ser20-phosphorylated p53 in Huh-7 cells (but not in HepG2 cells) after treatment, indicating CHK2's p53-independent role in cell cycle arrest in this cell line. 


\section{Discussion}

Inadequate outcomes in the treatment of HCC have necessitated the development of alternative approaches to chemotherapy. Recently, an H1 histamine receptor antagonist and serotonin receptor blocker, cyproheptadine, has been reported for its anticancer activity, which resulted in the induction of cancer cell apoptosis in mantle cell lymphoma, leukemia, and multiple myeloma $[13,14]$ and complete remission in two advanced HCC patients with lung metastases upon treatment with a combination of cyproheptadine and thalidomide [17]. Notably, despite its anti-angiogenic effects, thalidomide alone is insufficient treatment [26,27] and must be combined with other drugs or therapies in the treatment of cancer $[28,29]$. In addition, previous in vitro studies on human prostate carcinoma cells [30], human glioma cells [31], and Ehrlich ascites tumor cells [32] support the notion that thalidomide is not cytotoxic to cancer cells, indicating that the growth inhibition effect of thalidomide depends not only on the dosage of the drug but also on the cell type [33]. Consistently, we have demonstrated through our in vitro analysis that thalidomide treatment alone is not beneficial in terms of cellular cytotoxicity toward HCC cells (Additional file 1: Figure S2). In view of these results, cyproheptadine represents an attractive anticancer drug candidate, especially as it is already in clinical use as an antihistamine and appetite stimulant and is well tolerated and officially approved for years.

It is not known, however, whether antitumor concentrations of cyproheptadine are achievable in the human body. Daily treatment with cyproheptadine could produce serum levels of the drug higher than those observed after a single dose because of the slow elimination of cyproheptadine, which has a plasma half-life of metabolites of about $16 \mathrm{~h}$ [34]. Moreover, in a patient who overdosed on cyproheptadine and ethanol, tissue concentrations of cyproheptadine exceeded serum concentrations by a factor of up to 3 to 16 [16], indicating large-volume, extensive distribution of cyproheptadine into tissues [35]; the concentration of cyproheptadine in bile has been observed to reach as high as $30.7 \mathrm{mg} / \mathrm{L}(106.8 \mu \mathrm{M})$ [15], which is more than twice the concentration required to produce an antitumor effect in our in vitro study. Therefore, antitumor concentrations of cyproheptadine in human tissues might be attainable with daily high-dose treatment.

In the present study, we report the in vitro antiproliferative effects of cyproheptadine in HepG2 (p53 ${ }^{\text {wt/wt }}$, or p53-wild-type) and Huh-7 (p53 $3^{\text {del/mut }}$, or p53defective) HCC cells. The results clearly demonstrate that cyproheptadine has similar cytotoxic effects in both HCC cell lines despite their different p53 genetic backgrounds. Furthermore, since an SI value $<2$ indicates general toxicity of the agent [36], the SI values we determined for cyproheptadine (Table 1) reveal a high degree of cytotoxic selectivity toward HCC cells and entail greatly reduced adverse side effects associated with normal hepatocytes. Importantly, the high SI values of cyproheptadine make it a good candidate for an anticancer agent. The high cytotoxic selectivity of cyproheptadine should be further investigated.

Our cell cycle analysis revealed that cyproheptadine leads to cell cycle arrest in HepG2 in the G1 phase while arresting the cell cycle progression of Huh-7 cells at the G1/S transition (Figure 2A and B). To elucidate cyproheptadine's differential effects on the cell cycle in these cells, we examined the expression status of various cell cycle mediators. We were able to correlate cyproheptadine-induced G1 arrest in HepG2 cells with the induction of $\mathrm{p} 16^{\mathrm{INK} 4 \mathrm{~A}}$, which is known to inhibit the activation of cyclin-dependent protein kinase Cdk4/6 [37]. Importantly, we show for the first time the concurrent induction of HBP1 and $\mathrm{p} 16^{\mathrm{INK} 4 \mathrm{~A}}$ expression by cyproheptadine, and this parallel induction suggests that a common signaling event engages HBP1 and $\mathrm{p} 16^{\mathrm{INK} 4 \mathrm{~A}}$ expression. However, we cannot exclude the simultaneous effect of HBP1, a transcription factor, promoting the expression of $\mathrm{p} 16^{\mathrm{INK} 4 \mathrm{~A}}$ because the p16 ${ }^{\text {INK4A }}$ gene has been described as a novel target of transcription regulation by HBP1 [20]. As for cyproheptadine-induced G1/S arrest in Huh-7 cells, a different set of regulatory proteins may be involved. We show that cyproheptadine treatment induces the expression of p21 and p27 in Huh-7 cells (Figure 4A, right panel set). Because Huh-7 cells contain a defective mutation in the p53 gene, this p21 and p27 induction is independent of $\mathrm{p} 53$, as evidenced by an unchanged level of Ser20-phosphorylated p53 with and without treatment (Figure 5, right panel set). Consistently, p53-independent induction of p21 and p27 expression has been reported previously [38-40]. We also observed a significant time-dependent decrease in the hyperphosphorylated form of $\mathrm{Rb}$ in cyproheptadinetreated Huh-7 cells (Figure 4A, right panel set). Therefore, it is likely that the cyproheptadine-mediated induction of $\mathrm{p} 21$ and $\mathrm{p} 27$ expression contributes to the suppression of the kinase activity of the CDK2-cyclin E complex [41]. As a consequence, $\mathrm{Rb}$ remains in a hypophosphorylated state, leading to cell cycle arrest at the $\mathrm{G} 1 / \mathrm{S}$ transition [42-44].

We initially found that in response to cyproheptadine, p38 MAPK was rapidly and transiently activated in both HCC cell lines, as seen from the increased level of Thr180/Tyr182-phosphorylated p38 MAPK following treatment with the drug (Figure 5; Additional file 1: Figure S3). This result prompted our western blot analysis of cyproheptadine's effects on cell cycle-regulating proteins, including HBP1, p16 ${ }^{\mathrm{INK} 4 \mathrm{~A}}, \mathrm{p} 21$, and $\mathrm{p} 27$. The MAPK superfamily is known to play an important 
role in multiple cellular activities including proliferation, growth inhibition, differentiation, and apoptotic responses to a variety of extracellular stimuli [45-47]. Previous studies have demonstrated the involvement of p38 MAPK signaling in the regulation of cell cycle progression, especially at the G1/S phase $[48,49]$. Our results show that the cyproheptadine-mediated increase in p38 MAPK phosphorylation is followed by an immediate increase in HBP1 and $\mathrm{p} 16^{\mathrm{INK} 4 \mathrm{~A}}$ expression in HepG2 cells and a subsequent increase in p27 expression in Huh-7 cells (Figure 4; Additional file 1: Figure S3). These data suggest that activation of p38 MAPK signaling may serve as a common pathway by which cyproheptadine up-regulates HBP1, p16 ${ }^{\text {INK4A }}$, and p27. Accordingly, it has been reported that p38 MAPK can mediate HBP1 phosphorylation and thereby increase the stability and the protein level of HBP1 [50], and that p38 MAPK can facilitate G1/S arrest by upregulating $\mathrm{p} 16^{\mathrm{INK} 4 \mathrm{~A}}$ expression [51]. Our findings are also consistent with those of Kim et al. [52] and Mukhopadhyay et al. [41], who demonstrated that p38 MAPK activation leads to the induction of p21 and p27 expression in prostate cancer cells. As CHK2 activation has been found to be responsible for the induction of p21 expression in p53-deficient SK-BR-3 breast cancer cells and HaCaT immortalized keratinocytes [24], we were interested in determining whether CHK2 is activated in cyproheptadine-treated Huh-7 cells in which p21 expression is up-regulated. Our result shows for the first time that CHK2 is rapidly and increasingly activated in Huh-7 cells in response to cyproheptadine, as demonstrated by a time-dependent increase in the level of Thr68-phosphorylated CHK2 (Figure 5, right panel set). This result also reveals a p53-independent role for CHK2 in 221 induction that may contribute to tumor suppression and the outcome of cyproheptadine treatment. Furthermore, it has been reported that cyproheptadine altered cyclin D1 expression in myeloma and leukemia [13]. In our study, although cyproheptadine did not alter cyclin D1 expression in HepG2 cells, it did induce a moderate decrease in cyclin D1 expression in Huh-7 cells following treatment for $30 \mathrm{~h}$ (Figure 4B). It is likely that p38 MAPK can negatively regulate cyclin D1 at the level of transcription [53] or directly phosphorylate cyclin D1, leading to cyclin D1 ubiquitination and degradation [54]. Nevertheless, we show that the impact of cyproheptadine on cell cycle regulatory proteins is mediated through the activation of p38 MAPK activity. On the basis of our collective data, we present a schematic summary of the hypothesized effects of cyproheptadine on the cell cycle in the two HCC cell lines in Figure 6.

More than a few studies have reported that cell cycle arrest may lead to the induction of apoptosis $[55,56]$. Therefore, we were interested to see whether cyproheptadine could induce apoptosis in HCC cells. We observed that Huh-7 cells underwent cyproheptadine-induced apoptosis, as evidenced by the presence of a sub-G1 population
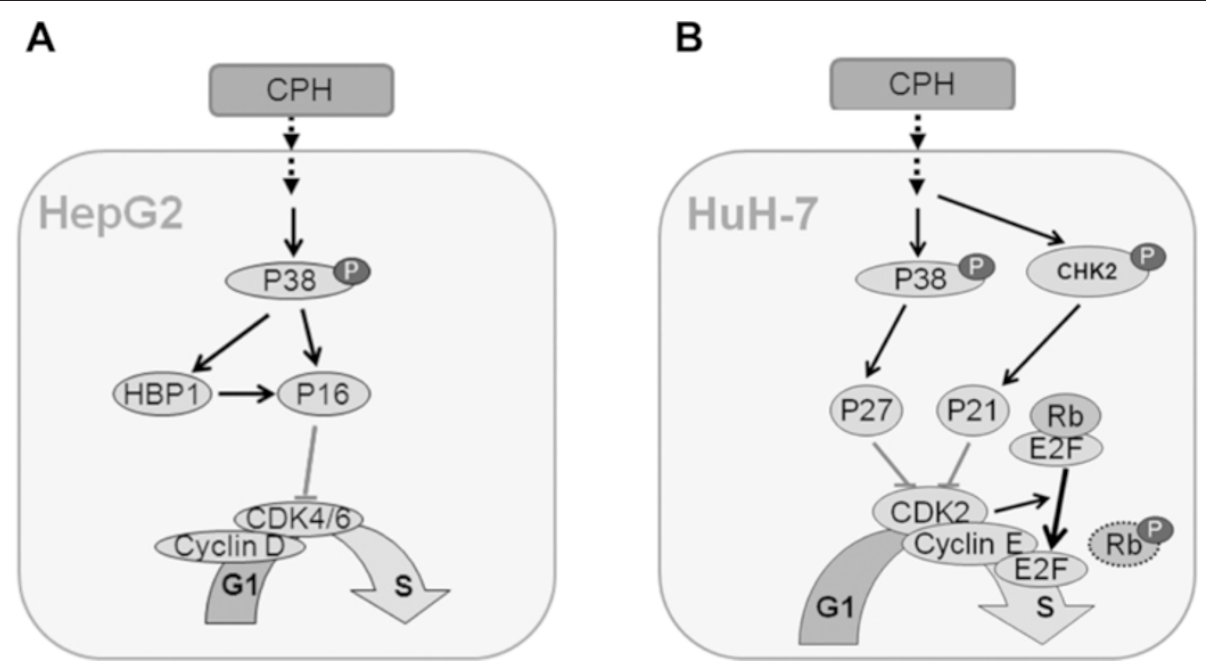

Figure 6 Schematic diagram of proposed effects of cyproheptadine on the cell cycle in HCC cells. (A) In HepG2 cells, cyproheptadine treatment causes significant activation of p38 MAPK activity, which subsequently mediates induction of p16 $6^{\mathrm{NK} 4 \mathrm{~A}}$ and HBP1. As a target of transcriptional regulation by HBP1, p16 $6^{\text {INKAA }}$ gene expression can be further promoted. Cytosolic p16 ${ }^{\text {INK } 4 A}$ may ultimately inhibit the activation of the cyclin-dependent protein kinase Cdk4/6, leading to cell cycle arrest in the G1 phase. (B) In Huh-7 cells, cyproheptadine treatment causes significant activation of p38 MAPK activity, which subsequently mediates the p53-independent induction of p27. At the same time, phosphorylation-activated CHK2 can promote p21 induction in a p53-independent way. The induced p21 and p27 contribute to a reduction in the kinase activity of the CDK2-cyclin E complex, which causes Rb to remain in a hypophosphorylated state, leading to cell cycle arrest at the G1/S transition. 
(Figure $2 \mathrm{~B}$ ), positive annexin $\mathrm{V}$ staining (Figure $3 \mathrm{~A}$ ), and an increased level of PARP and its cleavage product (Figure 3B) in the treated cells, indicating that cyproheptadine is a potent inducer of apoptosis. However, flow cytometry, annexin V-FITC apoptosis detection, and biochemical analyses revealed no significant increases in apoptosis in HepG2 cells after cyproheptadine treatment. This may be due to apoptotic pathway deficiencies [57] in this cancer cell line, in which the kinase, receptor-interacting protein 1 (RIP1), likely targets the mitochondria, leading to surplus formation of reactive oxygen species [58] and the subsequent induction of necrotic cell death [59-61]. In addition, cyproheptadine-induced activation of p38 MAPK signaling and the resulting induction of HBP1 and $\mathrm{p} 16^{\mathrm{INK} 4 \mathrm{~A}} \mathrm{ex}-$ pression may trigger premature senescence [20], which has been suggested to play a role in tumor suppression by reducing the replicative potential of cells [62] and is frequently detected in tumors obtained from patients who had undergone genotoxic chemotherapy [63].

\section{Conclusions}

In conclusion, the findings presented in this report demonstrate the anticancer potential of cyproheptadine in vitro in two human hepatocellular cancer cell lines, HepG2 and Huh-7. A high degree of selectivity for cancer cells, relatively low toxicity to normal hepatocytes, and a possible liver sequestration of the drug make cyproheptadine a good drug candidate for liver cancer chemotherapy; however, animal studies will be required to further validate these results in vivo. We have also demonstrated that cyproheptadine interferes with cell cycle progression via the activation of p38 MAPK activity in HepG2 cells and the activation of both p38 MAPK and CHK2 activities in Huh-7 cells, which subsequently mediate, through G1/S cell cycle regulatory proteins, the induction of apoptotic or non-apoptotic cell death in these liver cancer cells. Thus, we have revealed a novel cellular target for an interesting antihistamine drug whose effects encompass a wide range of biological events including growth inhibition and cell death induction. The results from our present study provide a strong foundation for further development of cyproheptadine as a novel treatment option that, in combination with other compounds, may be useful for human hepatocellular cancer prevention and therapy.

\section{Additional file}

Additional file 1: Figure S1. Cytotoxicity of low-dose cyproheptadine toward HepG2 (A) and Huh-7 cells (B). Cells were treated with various concentrations of cyproheptadine for $24 \mathrm{~h}$ or $48 \mathrm{~h}$. Cell viability data are presented as mean $\pm S D(n=6)$. Significant differences from the no-treatment control, determined by one-way ANOVA and Dunnett's comparison test, are indicated as ${ }^{*} p<0.05 ;{ }^{* *} p<0.01 ;{ }^{* *} p<0.001$. Figure $\mathbf{S 2}$ Cytotoxicity of thalidomide toward HepG2 and Huh-7 cells. Cells were treated with various concentrations of thalidomide for $24 \mathrm{~h}$ (A) or $48 \mathrm{~h}$ (B). Cell viability data are presented as mean $\pm S D(n=6)$. No significant differences from the no-treatment control were determined. Figure $\mathbf{S} \mathbf{3}$ Cyproheptadine induces p38 MAPK activation to mediate the expression of cell cycle regulatory proteins in HCC cells. HepG2 (A) and Huh-7 cells (B) were treated with $40 \mu \mathrm{M}$ cyproheptadine (column 2), with $10 \mu$ M of the p38 MAPK inhibitor SB202190 (column 4), or with a combination of $40 \mu \mathrm{M}$ cyproheptadine and $10 \mu \mathrm{M}$ SB202190 (column 3) for different lengths of time. Expression of Thr180/ Tyr182-phosphorylated p38 MAPK, p16, HBP1, p21, and p27 were analyzed by western blotting. A no-treatment control was also included (column 1). The level of Thr180/Tyr182-phosphorylated p38 MAPK increased in both HCC cell lines after treatment with cyproheptadine for 1-4 h ( $\mathrm{A}$ and B, column 2). The increase in phospho-p38 MAPK was significantly less after co-treatment with cyproheptadine and SB202190 (A and B, column 3). In HepG2 cells, the levels of p16 and HBP1 increased after treatment with cyproheptadine for 1-4 $\mathrm{h}$ (A, column 2) but decreased after co-treatment with cyproheptadine and SB202190 (A, column 3). In Huh-7 cells, both p21 and p27 increased in level after 1-2 $\mathrm{h}$ of treatment with cyproheptadine, whereas only p27 decreased after co-treatment with cyproheptadine and SB202190 (B, column 3).

\section{Competing interests}

The authors' declare that they have no competing interests.

\section{Authors' contributions}

$\mathrm{CDH}$ and YMF designed and directed the study. CWF, SYC, HYH, and YHC performed the experiments. CDH performed the statistical analysis. All authors have read and approved the final manuscript.

\section{Acknowledgments}

The authors' disclosed receipt of the following financial support for the research and/or authorship of this article: This study was supported by the Research Program of Ditmanson Medical Foundation Chia-Yi Christian Hospital, Chia-Yi, Taiwan, under Grant R101-25.

\section{Author details}

'Department of Internal Medicine, Ditmanson Medical Foundation Chia-Yi Christian Hospital, Chia-Yi, Taiwan. ${ }^{2}$ Department of Medical Research, Ditmanson Medical Foundation Chia-Yi Christian Hospital, Chia-Yi, Taiwan. ${ }^{3}$ Department of Biological Science, National Sun Yat-sen University, Kaohsiung, Taiwan.

Received: 19 April 2014 Accepted: 26 February 2015

Published online: 17 March 2015

\section{References}

1. Mittal S, El-Serag HB. Epidemiology of hepatocellular carcinoma: consider the population. J Clin Gastroenterol. 2013;47(Suppl):S2-6.

2. Jemal A, Bray F, Center MM, Ferlay J, Ward E, Forman D. Global cancer statistics. CA Cancer J Clin. 2011;61(2):69-90.

3. El-Serag HB. Hepatocellular carcinoma. N Engl J Med. 2011;365(12):1118-27.

4. Jan CF, Chen CJ, Chen $\mathrm{HH}$. Causes of increased mortality from hepatocellular carcinoma in high incidence country: Taiwan experience. J Gastroenterol Hepatol. 2005;20(4):521-6.

5. Villanueva A, Llovet JM. Targeted therapies for hepatocellular carcinoma. Gastroenterology. 2011;140(5):1410-26.

6. Finn RS. Development of molecularly targeted therapies in hepatocellular carcinoma: where do we go now? Clin Cancer Res. 2010;16(2):390-7.

7. Llovet JM, Ricci S, Mazzaferro V, Hilgard P, Gane E, Blanc JF, et al. Sorafenib in advanced hepatocellular carcinoma. N Engl J Med. 2008;359(4):378-90.

8. Aravalli RN, Steer CJ, Cressman EN. Molecular mechanisms of hepatocellular carcinoma. Hepatology. 2008:48(6):2047-63.

9. Finn RS. Current and future treatment strategies for patients with advanced hepatocellular carcinoma: role of mTOR inhibition. Liver Cancer. 2012;1(3-4):247-56.

10. Topp ZZ, Sigal DS. Beyond chemotherapy: systemic treatment options for hepatocellular carcinoma. Transl Cancer Res. 2013;2(6):482-91.

11. Klein GL, Galant SP. A comparison of the antipruritic efficacy of hydroxyzine and cyproheptadine in children with atopic dermatitis. Ann Allergy. 1980;44(3):142-5. 
12. Mattox TW. Treatment of unintentional weight loss in patients with cancer Nutr Clin Pract. 2005;20(4):400-10.

13. Mao X, Liang SB, Hurren R, Gronda M, Chow S, Xu GW, et al. Cyproheptadine displays preclinical activity in myeloma and leukemia. Blood. 2008;112(3):760-9

14. Paoluzzi L, Scotto L, Marchi E, Seshan VE, O'Connor OA. The anti-histaminic cyproheptadine synergizes the antineoplastic activity of bortezomib in mantle cell lymphoma through its effects as a histone deacetylase inhibitor. $\mathrm{Br} J$ Haematol. 2009;146(6):656-9.

15. Hargrove V, Molina DK. A fatality due to cyproheptadine and citalopram. J Anal Toxicol. 2009;33(8):564-7.

16. Levine B, Green-Johnson D, Hogan S, Smialek JE. A cyproheptadine fatality. J Anal Toxicol. 1998;22(1):72-4.

17. Feng YM, Feng CW, Chen SC, Hsu CD. Unexpected remission of hepatocellular carcinoma (HCC) with lung metastasis to the combination therapy of thalidomide and cyproheptadine: report of two cases and a preliminary HCC cell line study. BMJ Case Rep. 2012. doi:10.1136/bcr- 2012-007180.

18. Li J, Cao B, Zhou S, Zhu J, Zhang Z, Hou T, et al. Cyproheptadine-induced myeloma cell apoptosis is associated with inhibition of the PI3KAKT signaling. Eur J Haematol. 2013;91(6):514-21.

19. Prayong P, Barusrux S, Weerapreeyakul N. Cytotoxic activity screening of some indigenous Thai plants. Fitoterapia. 2008;79(7-8):598-601.

20. Li H, Wang W, Liu X, Paulson KE, Yee AS, Zhang X. Transcriptional factor HBP1 targets P16(INK4A), upregulating its expression and consequently is involved in Ras-induced premature senescence. Oncogene. 2010;29(36):5083-94.

21. Daly JM, Olayioye MA, Wong AM, Neve R, Lane HA, Maurer FG, et al. NDF/ heregulin-induced cell cycle changes and apoptosis in breast tumour cells: role of PI3 kinase and p38 MAP kinase pathways. Oncogene. 1999;18(23):3440-51.

22. Thornton TM, Rincon M. Non-classical p38 map kinase functions: cell cycle checkpoints and survival. Int J Biol Sci. 2009;5(1):44-51.

23. Jack MT, Woo RA, Hirao A, Cheung A, Mak TW, Lee PW. Chk2 is dispensable for p53-mediated G1 arrest but is required for a latent p53-mediated apoptotic response. Proc Natl Acad Sci U S A. 2002;99(15):9825-9.

24. Aliouat-Denis CM, Dendouga N, Van den Wyngaert I, Goehlmann H, Steller $\mathrm{U}$, van de Weyer I, et al. p53-independent regulation of p21Waf1/Cip1 expression and senescence by Chk2. Mol Cancer Res. 2005:3(11):627-34

25. Hailfinger S, Jaworski M, Marx-Stoelting P, Wanke I, Schwarz M. Regulation of P53 stability in p53 mutated human and mouse hepatoma cells. Int J Cancer J Int du Cancer. 2007;120(7):1459-64.

26. Ruddy JM, Majumdar SK. Antitumorigenic evaluation of thalidomide alone and in combination with cisplatin in DBA2/J Mice. J Biomed Biotechnol. 2002;2(1):7-13.

27. McMeekin DS, Sill MW, Benbrook D, Darcy KM, Stearns-Kurosawa DJ, Eaton $L$, et al. A phase II trial of thalidomide in patients with refractory endometrial cancer and correlation with angiogenesis biomarkers: a Gynecologic Oncology Group study. Gynecol Oncol. 2007;105(2):508-16.

28. Oz ES, Aydemir E, Korcum AF, Fiskin K. Thalidomide and irradiation combination therapy increases substance $P$ levels in vitro. Exp Ther Med. 2011;2(3):529-35.

29. Weber D, Rankin K, Gavino M, Delasalle K, Alexanian R. Thalidomide alone or with dexamethasone for previously untreated multiple myeloma. J Clin Oncol. 2003;21(1):16-9.

30. Gutman M, Szold A, Ravid A, Lazauskas T, Merimsky O, Klausner JM. Failure of thalidomide to inhibit tumor growth and angiogenesis in vivo. Anticancer Res. 1996;16(6B):3673-7.

31. Moreira AL, Friedlander DR, Shif B, Kaplan G, Zagzag D. Thalidomide and a thalidomide analogue inhibit endothelial cell proliferation in vitro. J Neurooncol. 1999:43(2):109-14.

32. Dipaolo JA, Wenner CE. Thalidomide: effects on ehrlich ascites tumor cells in vitro. Science. 1964;144(3626):1583.

33. Itasaka S, Komaki R, Herbst RS, Shibuya K, Shintani T, Hunter NR, et al. Endostatin improves radioresponse and blocks tumor revascularization after radiation therapy for A431 xenografts in mice. Int J Radiat Oncol Biol Phys. 2007;67(3):870-8.

34. Paton DM, Webster DR. Clinical pharmacokinetics of H1-receptor antagonists (the antihistamines). Clin Pharmacokinet. 1985;10(6):477-97.

35. Hintze KL, Wold JS, Fischer LJ. Disposition of cyproheptadine in rats, mice, and humans and identification of a stable epoxide metabolite. Drug Metab Dispos. 1975;3(1):1-9.
36. Koch A, Tamez P, Pezzuto J, Soejarto D. Evaluation of plants used for antimalarial treatment by the Maasai of Kenya. J Ethnopharmacol. 2005;101(1-3):95-9.

37. Roussel MF. The INK4 family of cell cycle inhibitors in cancer. Oncogene. 1999;18(38):5311-7.

38. Biggs JR, Kudlow JE, Kraft AS. The role of the transcription factor Sp1 in regulating the expression of the WAF1/CIP1 gene in U937 leukemic cells. J Biol Chem. 1996;271(2):901-6.

39. Chinni SR, Li Y, Upadhyay S, Koppolu PK, Sarkar FH. Indole-3-carbinol (I3C) induced cell growth inhibition, G1 cell cycle arrest and apoptosis in prostate cancer cells. Oncogene. 2001;20(23):2927-36.

40. Liu TZ, Chen CY, Yiin SJ, Chen CH, Cheng JT, Shih MK, et al. Molecular mechanism of cell cycle blockage of hepatoma SK-Hep-1 cells by Epimedin $\mathrm{C}$ through suppression of mitogen-activated protein kinase activation and increased expression of CDK inhibitors p21(Cip1) and p27(Kip1). Food Chem Toxicol. 2006:44(2):227-35.

41. Mukhopadhyay I, Sausville EA, Doroshow JH, Roy KK. Molecular mechanism of adaphostin-mediated G1 arrest in prostate cancer (PC-3) cells: signaling events mediated by hepatocyte growth factor receptor, c-Met, and p38 MAPK pathways. J Biol Chem. 2006;281(49):37330-44.

42. Akiyama T, Ohuchi T, Sumida S, Matsumoto K, Toyoshima K Phosphorylation of the retinoblastoma protein by cdk2. Proc Natl Acad Sci U S A. 1992;89(17):7900-4.

43. Harper JW, Adami GR, Wei N, Keyomarsi K, Elledge SJ. The p21 Cdk-interacting protein Cip1 is a potent inhibitor of G1 cyclin-dependent kinases. Cell. 1993;75(4):805-16.

44. Abbas T, Dutta A. p21 in cancer: intricate networks and multiple activities. Nat Rev Cancer. 2009:9(6):400-14.

45. Roovers K, Assoian RK. Integrating the MAP kinase signal into the G1 phase cell cycle machinery. Bioessays. 2000;22(9):818-26.

46. Han J, Sun P. The pathways to tumor suppression via route $\mathrm{p} 38$. Trends Biochem Sci. 2007:32(8):364-71.

47. Hui L, Bakiri L, Stepniak E, Wagner EF. p38alpha: a suppressor of cell proliferation and tumorigenesis. Cell Cycle. 2007;6(20):2429-33.

48. Lafarga V, Cuadrado A, Lopez De Silanes I, Bengoechea R, FernandezCapetillo O, Nebreda AR. p38 Mitogen-activated protein kinase- and HuR-dependent stabilization of p21(Cip1) mRNA mediates the G(1)/S checkpoint. Mol Cell Biol. 2009:29(16):4341-51.

49. Kishi H, Nakagawa K, Matsumoto M, Suga M, Ando M, Taya $Y$, et al. Osmotic shock induces $\mathrm{G} 1$ arrest through p53 phosphorylation at Ser33 by activated p38MAPK without phosphorylation at Ser15 and Ser20. J Biol Chem. 2001;276(42):39115-22

50. Xiu M, Kim J, Sampson E, Huang CY, Davis RJ, Paulson KE, et al. The transcriptional repressor HBP1 is a target of the p38 mitogen-activated protein kinase pathway in cell cycle regulation. Mol Cell Biol. 2003;23(23):8890-901.

51. Bulavin DV, Phillips C, Nannenga B, Timofeev O, Donehower LA, Anderson CW, et al. Inactivation of the Wip1 phosphatase inhibits mammary tumorigenesis through p38 MAPK-mediated activation of the p16(Ink4a)-p19 (Arf) pathway. Nat Genet. 2004;36(4):343-50.

52. Kim SJ, Johnson M, Koterba K, Herynk MH, Uehara H, Gallick GE. Reduced c-Met expression by an adenovirus expressing a c-Met ribozyme inhibits tumorigenic growth and lymph node metastases of PC3-LN4 prostate tumor cells in an orthotopic nude mouse model. Clin Cancer Res. 2003;9(14):5161-70

53. Lavoie JN, L'Allemain G, Brunet A, Muller R, Pouyssegur J. Cyclin D1 expression is regulated positively by the p42/p44MAPK and negatively by the p38/HOGMAPK pathway. J Biol Chem. 1996;271(34):20608-16.

54. Casanovas O, Miro F, Estanyol JM, Itarte E, Agell N, Bachs O. Osmotic stress regulates the stability of cyclin D1 in a p38SAPK2-dependent manner. J Biol Chem. 2000:275(45):35091-7.

55. Hartwell LH, Kastan MB. Cell cycle control and cancer. Science. 1994;266(5192):1821-8.

56. Vermeulen K, Berneman ZN, Van Bockstaele DR. Cell cycle and apoptosis. Cell Prolif. 2003:36(3):165-75.

57. Okada H, Mak TW. Pathways of apoptotic and non-apoptotic death in tumour cells. Nat Rev Cancer. 2004;4(8):592-603.

58. Festjens N, Vanden Berghe T, Cornelis S, Vandenabeele P. RIP1, a kinase on the crossroads of a cell's decision to live or die. Cell Death Differ. 2007;14(3):400-10

59. Lin Y, Choksi S, Shen HM, Yang QF, Hur GM, Kim YS, et al. Tumor necrosis factor-induced nonapoptotic cell death requires receptor-interacting 
protein-mediated cellular reactive oxygen species accumulation. J Biol Chem. 2004;279(11):10822-8.

60. Lopez-Sanchez N, Rodriguez JR, Frade JM. Mitochondrial c-Jun NH2-terminal kinase prevents the accumulation of reactive oxygen species and reduces necrotic damage in neural tumor cells that lack trophic support. Mol Cancer Res. 2007;5(1):47-60.

61. Kim CH, Han Sl, Lee SY, Youk HS, Moon JY, Duong HQ, et al. Protein kinase C-ERK1/2 signal pathway switches glucose depletion-induced necrosis to apoptosis by regulating superoxide dismutases and suppressing reactive oxygen species production in A549 lung cancer cells. J Cell Physiol. 2007;211(2):371-85.

62. Kahlem P, Dorken B, Schmitt CA. Cellular senescence in cancer treatment: friend or foe? J Clin Invest. 2004;113(2):169-74.

63. te Poele RH, Okorokov AL, Jardine L, Cummings J, Joel SP. DNA damage is able to induce senescence in tumor cells in vitro and in vivo. Cancer Res. 2002;62(6):1876-83.

\section{Submit your next manuscript to BioMed Central and take full advantage of:}

- Convenient online submission

- Thorough peer review

- No space constraints or color figure charges

- Immediate publication on acceptance

- Inclusion in PubMed, CAS, Scopus and Google Scholar

- Research which is freely available for redistribution 